\title{
Um manuscrito inédito do naturalista e político Martim Francisco Ribeiro de Andrada*
}

\author{
An unpublished manuscript by naturalist and politician \\ Martim Francisco Ribeiro de Andrada
}

Alex Gonçalves Varela

Pós-doutorando do Museu de Astronomia e Ciências Afins/Ministério da Ciência e Tecnologia
VARELA, Alex Gonçalves. Um manuscrito inédito do naturalista e político Martim Francisco Ribeiro de Andrada. História, Ciências, Saúde - Manguinhos, Rio de Janeiro, v.14, n.3, p.973-990, jul.-set. 2007.

Martim Francisco Ribeiro de Andrada foi um dos expoentes da ilustração luso-americana. Seus perfis de naturalista e político são indissociáveis, característica típica dos ilustrados do Setecentos. No cargo de ministro da Fazenda, redigiu a "Memória sobre a estatística ou análise dos verdadeiros princípios desta ciência e sua aplicação à riqueza, artes e poder do Brasil", estudo que permaneceu inédito até os nossos dias, no arquivo do Instituto Histórico e Geográfico Brasileiro. O texto demonstra o quanto ciência e política caminhavam amalgamadas no final do século XVIII e início do XIX.

PALAVRAS-CHAVE: história das ciências no Império português; Martim Francisco Ribeiro de Andrada; história da estatística; história do Brasil.

VARELA, Alex Gonçalves. An unpublished manuscript by naturalist and politician Martim Francisco Ribeiro de Andrada. História, Ciências, Saúde - Manguinhos, Rio de Janeiro, v.14, n.3, p.973-990, July-Sept. 2007.

Martim Francisco Ribeiro de Andrada was a leading Portuguese American scholar. His activities as a naturalist and politician are intimately linked, which was commonplace in the eighteenth century. As Minister of Finance, he wrote "Memória sobre a estatística ou análise dos verdadeiros princípios desta ciência e sua aplicação à riqueza, artes e poder do Brasil" [Memory on statistics or an analysis of the true principles of this science and its application to the wealth, arts and power of Brazil], an as yet unpublished work that is held in the Instituto Histórico e Geográfico Brasileiro archive. The text shows how closely science and politics were intertwined in the late eighteenth and early nineteenth centuries.

KEYWORDS: history of science in the Portuguese empire; Martim Francisco Ribeiro de Andrada; history of statistics; history of Brazil. 
* Este trabalho integra o projeto Contribuição à

História das Ciências Paleontológicas no Sul da América (17801911), coordenado pela doutora Maria Margaret Lopes e apoiado pela Fapesp. pós longo período desenvolvendo atividades de naturalista à 1 frente da administração das minas da capitania de São Paulo, Martim Francisco ingressou na carreira política de estadista e parlamentar no ano de 1820, quando foi criada a Junta Governativa da Capitania, tendo ocupado o cargo de seu secretário. No ano de 1822, com a convocação de seu irmão José Bonifácio para ser o primeiro-ministro de d. Pedro, foi convidado para integrar o 'Ministério dos Andradas'. Martim ocupou o cargo de ministro e secretário de Estado dos Negócios da Fazenda e presidente do Tesouro Público, tornando-se o primeiro ministro da Fazenda do Brasil.

Tudo leva a crer que nesse período Martim Francisco redigiu a "Memória sobre a estatística ou análise dos verdadeiros princípios desta ciência, e sua aplicação à rique-za, artes e poder do Brasil". A dissertação foi encontrada entre os seus manuscritos no Arquivo do Instituto Histórico e Geográfico Brasileiro (Lata 18 Doc. 21), sem a data e o local em que foi escrito. Tendo em vista as condições desse documento, de sua escrita (à tinta, frente e verso), foi considerado de difícil leitura e permaneceu de certa forma desconhecido do público acadêmico. As referências ao documento, até o momento, foram feitas de forma indireta, ou seja, por meio de textos de terceiros, como a conferência proferida por Artur de Souza Costa no Instituto Histórico e Geográfico Brasileiro (IHGB) e reproduzida no artigo "Martim Francisco", na Revista Brasileira de Estatística, em 1945 (Senra, 2006).

No texto, observa-se o interesse do autor pela manutenção da união entre os Reinos de Brasil e Portugal. Ele registra que o movia a realizar o projeto de "exata e rigorosa estatística do Brasil" era "o amor do bem público, que ainda dura no coração dos bons portugueses, o desejo da estima e consideração que o Soberano e a Pátria tributam e consagram aos seus beneméritos". Portanto, no momento em que redigiu a Memória ainda afirmava-se como um português, fiel vassalo da Monarquia dos Braganças, identificandose politicamente com o Estado português. Contudo, mesmo longe de revelar intenção separatista e aceitando ainda o princípio da integridade e indissolubilidade do Reino Unido de Portugal e do Brasil, Martim Francisco não deixava de chamar a atenção para a importância do projeto estatístico para o conhecimento geral do 'Reino do Brasil', elemento de extrema importância para a futura "independência política deste Reino".

Foi necessário esperar pela Revolução Francesa para que a informação estatística deixasse de ser um bem privado do monarca para se tornar um bem coletivo e para que fosse objeto de uma publicidade declarada (Revel, 1989). Longo processo histórico - de caráter europeu, que teve na França seu local mais acentuado.

No final do século XVIII e início do XIX, as ciências tinham-se tornado parte importante da ação do próprio governo, particular- 
mente as mais novas, como, por exemplo, a estatística, que oferecia a possibilidade de controlar e rever as necessidades em recursos sociais e naturais de que os governos careciam para colocar em prática as suas políticas reformistas (Outram, 2001, p.98).

Foi nesse contexto que Martim Francisco Ribeiro de Andrada apresentou sua "Memória". Fazia-se necessário, nesses primeiros momentos de vida autônoma do país, dar início ao processo de conhecimento dessa imensa 'terra incógnita', marcada pelas enormes distâncias geográficas, pela dissociação das províncias, pelos regionalismos, pela falta de meios de comunicação e transportes, além das enormes distâncias sociais que separavam a reduzida 'boa gente' (os letrados) da massa inculta, composta de escravos, negros e mulatos livres ou alforriados, descendentes de escravos e brancos miseráveis. Era, portanto, necessário contabilizar pessoas e riquezas, esquadrinhar todos os pormenores do território, para que através das informações coletadas se pudesse fazer do 'Reino do Brasil' uma nação moderna, inserida no rol das nações 'civilizadas'.

A dissertação apresentada por Martim Francisco foi divida em cinco capítulos.

Nela, Martim Francisco define a estatística como uma ciência auxiliar do Estado, de sua administração e de sua gestão corrente, como método de descrição e de análise destinado a apresentar a tábua dos recursos e das forças que o constituem. Tal concepção muito se aproxima daquela proposta pelos teóricos da época napoleônica, como Chaptal, que a definiam como "exposição metódica e positiva dos objetos que compõe a riqueza e a força de um Estado" (Bourguet, 1989, p.14). As cifras teriam um lugar nesse trabalho estatístico, mas a análise qualitativa era essencial, deixando transparecer, mais que tudo, a vocação de inventário, descrição e análise que caracterizou na época moderna a estatística: uma 'tábua física do Estado'.

No estudo, observa-se que o método proposto por Martim Francisco recorria a determinados procedimentos utilizados pelo naturalista em sua prática científica no campo da história natural. A descrição, inventariação e classificação, características dos trabalhos no campo das ciências naturais, deveriam também estar presentes no trabalho daqueles que elaborariam o quadro estatístico do 'Reino do Brasil'. No último item da dissertação, o autor deixa transparecer o 'utilitarismo científico', característica do pensamento científico moderno, ao apresentar um sumário das utilidades que o conhecimento estatístico poderia oferecer ao governo do Brasil.

Martim Francisco, como um típico Ilustrado do século XVIII, revelava sua crença nas ações futuras. Argumentava que os trabalhos estatísticos proporcionariam vantagens futuras ao governo do Brasil, tais como conhecimento do território, dos rios, dos portos, da costa litorânea, dos vegetais, dos animais, dos minerais e 
dos diferentes climas. Os levantamentos realizados ofereceriam ao governo os meios de estimular a agricultura, a indústria e o comércio e apresentariam os remédios que ajudariam a superar os entraves para que "este Reino marche seguro e chegue depressa aos altos destinos de glória e de poder para que a natureza o saltasse". Portanto, era necessário tudo registrar e contar, por um olhar que era político mas também enciclopédico, uma vez que serviria às ciências, às artes e à administração (Martin, 2001).

No esforço de inventariar o país, Martim Francisco estabeleceu que o quadro estatístico fosse dividido em oito partes: extensão e divisões do território; população e suas diferentes relações com as outras partes da estatística e da economia política; produções dos terrenos das minas e pescas e avaliação das riquezas que produzem; indústria, sua importância, suas espécies, seus produtos e os salários que paga; comércio, seus meios, sua extensão e divisão e suas relações com as outras fontes de riqueza; navegação mercante, seu estado, seu sistema e seus resultados na balança das forças nacionais; rendas do Estado, suas fontes, produto de cada uma, despesas da percepção, despesas do mesmo estado, e uma exposição do sistema geral seguido na administração das nossas finanças; forças de terra e de mar, ou quadro dos diferentes corpos que as compõem, com a declaração circunstanciada de tudo o que lhes pertence. As oito divisões constituiriam a base das tabelas elaboradas pelo autor.

A "Memória" de Martim Francisco apresenta oito tabelas anexas, em que constam os assuntos a serem inventariados: território, população, produções, indústria, comércio, navegação, rendas e forças da terra. Senra (2006) destaca, ainda, o fato de que naquela época era mais comum a denominação 'quadros' ou 'mapas', em lugar de 'tabelas', termo preferido por Martin Francisco.

Martim Francisco revela a riqueza do pensamento ilustrado no ambiente luso-americano da virada do século XVIII para o XIX. Em sua trajetória de vida, a ciência e a política sempre caminharam lado a lado. Em primeiro lugar, porque estava engajado no projeto político de modernização do Império Português encabeçado por dom Rodrigo de Sousa Coutinho, ministro do Ultramar da rainha dona Maria. A ciência foi o elemento que forneceu ao ministro o referencial metodológico para mapear e pesquisar as 'produções naturais' do Reino e da Colônia com o intuito de descobrir novas fontes de recursos econômicos que pudessem promover o desenvolvimento e a modernização da nação portuguesa e das partes que compunham o seu Império Atlântico, sobretudo o Brasil. Em segundo lugar, ao ser chamado para atuar como estadista e parlamentar, Martim Francisco passou a formular os projetos políticos para a jovem nação brasileira e os meios possíveis para inseri-la no concerto das nações civilizadas. Do império luso-americano ao 
império do Brasil, foi um homem extremamente atualizado com o pensamento europeu e buscou aplicar e experimentar novos conhecimentos à sua comunidade local.

O documento aqui transcrito é exemplar para demonstrar o quanto ciência e política caminhavam amalgamadas, naquele período, nas concepções e práticas dos naturalistas. Constitui um arrazoado sobre o que é a ciência da estatística, suas diferenças em relação a outras ciências como economia e aritmética política, bem como sobre as utilidades da ciência para servir ao Estado.

\section{REFERÊNCIAS BIBLIOGRÁFICAS}

Bourguet, Marie-Noëlle 1989

Costa, Artur de Souza jan.-mar. 1945

Martin, Olivier 2001

Outram, Dorinda 2001

Revel, Jacques 1989

Senra, Nelson de Castro 2006
Déchiffrer la France: la statistique départamentale à l'époque napoléonienne. Paris: Éditions des Archives Contemporaines.

Martim Francisco. Revista Brasileira de Estatística, Rio de Janeiro, v.6, n.21, p.65-71.

Da estatística política à sociologia estatística. Desenvolvimento e transformações da análise estatística da sociedade (séculos XVII-XIX). Revista Brasileira de História, São Paulo, v.21, n.41, p.13-44.

O iluminismo.

Lisboa: Temas \& Debates.

A invenção da sociedade.

Rio de Janeiro: Bertrand Brasil.

História das estatísticas brasileiras.

Rio de Janeiro: IBGE. 


\title{
Memória Sobre a Estatística ou Análise dos Verdadeiros Princípios Desta Ciência e Sua Aplicação à Riqueza, Artes e Poder do Brasil
}

\author{
Martim Francisco Ribeiro de Andrada
}

\section{Capítulo I - Origem e Antiguidade da Estatística}

A ciência de governar é contemporânea da sociedade. Desde o momento em que muitos homens se reúnem em um corpo social, desde então nunca uma polícia, que impeça ou reprima os efeitos das paixões prejudiciais de cada um; desde então um chefe governa em nome e com poder de todos. É desta ordem de coisas que emana a constituição e independência política dos Estados; é desta ordem de coisas que cada Estado tem seus direitos, suas pretensões, seu sistema de interesse privativo e muitas vezes contrário aos de seus vizinhos.

Quando uma semelhante associação da qual tem ainda hoje exemplos na maior parte dos povos da África, quando ela, digo, faz progressos quando a guerra se torna uma arte, a polícia um sistema de perfeição e a justiça única regra dos Magistrados; então o Chefe de Estado põe todo o seu esmero em estabelecer e firmar as preponderâncias do seu povo sobre os outros povos. Esta tendência é natural ao espírito da sociedade, porque o amor de poder e de domínio é talvez a paixão mais ativa do homem e, por conseguinte dos Governos.

A guerra desde sua origem, teatro horrível de mil paixões brutais, de calamidades, misérias, combates e de morte, deve-se em grande parte a este espírito de ambição, primeiro móvel de todas as determinações no berço das sociedades políticas e da mesma sorte que os princípios, pois fica o espírito do governo, que sucederão aos hábitos guerreiros incompatíveis com o progresso da civilização, devem-se ao estabelecimento da igualdade de poder entre muitos Estados, que a força e ordem das coisas produziram. É nesses tempos de tranqüilidade e sossego, que o Chefe do poder público começa a calcular os recursos, as forças e o poder do Estado pela extensão do seu Território, sua população e sua riqueza. Não de outra arte nasceu a Estatística.

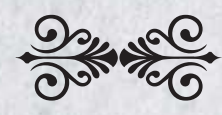




\section{Capítulo II - Etimologia da Palavra Estatística, Existência Dela Como Fator nos Governos Modernos e Antigos}

Ou a Estatística teve sua origem da palavra Statera (balança ) por pesar a força, riqueza de um Estado, comparando-a com sua situação anterior, ou com a de outras nações; ou da palavra Status, por oferecer essa ciência o quadro da situação atual de um Estado; ou finalmente da alemã Hadf / cidades, nome de quais se serviram os primeiros que empregaram a palavra Estatística para exprimir o exame e análise das forças e riqueza de uma cidade, é sempre indubitável, que esta ciência tem como fator a mesma integridade, que as formas de governo antecedam a qualquer que seja a etimologia, ou época de seu nome. Fazer o recenseamento das cidades e de suas fortunas quando ela lançou as bases primeiras desse majestoso edifício que sobrevive ainda hoje a sua destruição, ela deu um exemplo de emprego que se pode fazer dos conhecimentos estatísticos; E este exemplo foi continuado na firme persuasão de que sua obra a não ser assim seria arriscada e precária; de que seus projetos de engrandecimento [ilegível].

Ao tempo da República e mesmo no dos Imperadores que não [ilegível] princípios eternos da justiça e ordem pública, os recenseamentos dos cidadãos repetiu-se sempre um meio de reconhecer a prosperidade ou fraqueza, e de avaliar a quantidade de homens que se podia recrutar sem arrancar as artes e a cultura, os braços precisos. Plínio, o naturalista, nos concorreu muitas descrições das artes e algumas indagações sobre a cultura e o comércio, o que se prova que em seu tempo e antes dele, se calculavam e comparavam as diversas fontes de riqueza. E o que nos resta escrito sobre a administração das finanças romanas, mostra que o governo mandava extrair tabelas exatas do número de habitantes de cada província do Império, das rendas territoriais e de todos os ramos da fartura pública.

O quadro das finanças da África traçado pela [sic] elegante de Xenofontes prova que os Gregos cuidavam em calcular as forças da República para conhecer o grau de seu poder, que os Estatísticos e oradores se [ilegível] no conhecimento dos princípios e que hoje compõem a Estatística, a qual então se comprova, no exame refletido e circunstanciado da riqueza e poder nacional; a bem que não se [ilegível] tais conhecimentos a um sistema científico, nem por isso possuíram mais seus elementos e resultados de que sempre [ilegível], quando tratavam de negócios públicos.

Quando sob as ruínas do Império do Ocidente se elevaram as Monarquias modernas, quando as desordens do feudalismo sucederam à ordem pública, a fortuna e segurança dos vassalos se achou protegida pelas leis, o uso de uma estatística manteve-se, desenvolveu-se, e com o tempo adiantou-se entre iguais governos. Sirva de exemplo a Alemanha, de onde vieram as primeiras obras que nos fizeram conhecer esta ciência; da Inglaterra e da França sirvam de exemplo os grandes e excelentes escritos de Potty, D'avemant, Young e Sants, os de Necker, Lavoisier, Poloian e Penchet. Em geral, ou lançamos os olhos para as instituições dos povos antigos, ou para a época do renascimento da civilização na Europa, época em que a riqueza e o comércio chamaram a si a atenta mira dos soberanos, veremos sempre que dos conhecimentos estatísticos resultou a estabilidade, a glória e prosperidade de seus sistemas políticos.

Se iguais trabalhos estatísticos fizeram com que tantos se avantajassem em riquezas mencionadas com quanta maior razão deve o Brasil, grande pela sua vasta extensão e 
fertilidade de seu território; cortado por imensos rios e alguns já navegáveis; senhor de uma extensa costa semeada de ótimos portos; abundante de matas; os seus minerais e outras preciosidades; e pela diversidade de seu clima, que em si encerra promovedor das produções rurais mais raras? O Brasil, finalmente, que em si contém todos os mananciais de riqueza e de força? Sem dúvida, iguais trabalhos devem oferecer ao Governo os meios de animar a cultura, existir a indústria, promover o comércio e mirando dificuldades extrair a larga vereda, por onde este reino marche seguro e chegue depressa aos altos destinos de glória e de poder para que a natureza o saltasse.

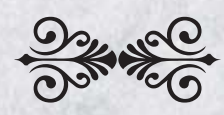

\section{Capítulo III - Distinção Entre a Estatística, a Economia e Aritmética Política. Rigorosa Distinção da Primeira, e Objetos em que se Divide}

Em grande número de escritos e trabalhos dados à luz nestes últimos tempos, não se tem demarcado rigorosamente os limites que separam a Estatística da Economia Política, ou falando com mais exatidão, de ordinário se tem associado o conhecimento dos resultados, as considerações que eles faziam nascer para o aumento da prosperidade pública. Este modo de apresentar a ciência nada teria de prejudicial, talvez mesmo tivesse sido útil, se o espírito de exagero não tivesse até certa época apoderada de todos que se metia a escrever sobre matérias administrativas. Eu falo dos economistas que tanta voga teve em França, e que à exceção de suas boas intenções, terminou em um verdadeiro caos a ciência de administração, pela ausência de toda a base e de todos os princípios.

Mas a Economia Política tendo, segundo Garnier, por objeto a considerar as leis de transição das sociedades e indagar os meios que as podem tornar felizes e poderosas, é, sem dúvida, uma ciência motivada por escudar-se na experiência e conhecimento de fatos. Debaixo deste ponto de vista, longe de ser uma Metafísica confusa e capaz de todas as explicações e de todos os erros, é, pelo contrário, um corpo de doutrina apropriado tanto para a solução de um problema administrativo, quanto para o estabelecimento e conservação de um bom sistema financeiro.

Desta vantagem, devido à feliz associação das duas ciências, se não deve inferir e argumentar a fazer de sua conjunção, como erradamente pensaram alguns escritores, porquanto cada uma tem seus limites, e seu objetivo fixo. A economia concede, engendra e põe em execução aquelas verdades, ou princípios administrativos que o raciocínio munido da comparação dos fatos, reconheceu por incontestavelmente úteis. A estatística encarrega-se de preparar os elementos que devem encaminhar o espírito; recolhe e aproveita separadamente os conhecimentos destes fatos, e com eles forma um agregado e resultados fundados em análise tão rigorosa, que produzirão uma convicção única, que se pode e deve desejar em matérias administrativas.

A Estatística difere igualmente da Aritmética Política, por quanto, a segunda, longe de proceder em suas operações por meio da análise e obter seus resultados pela enumera- 
ção dos objetos, como acontece à primeira, substitui, pelo contrário, o cálculo a estes meios, e de um dado mais ou menos provável e certo tira conseqüências que estabelece e dá por fatos. A Estatística pode também compreender, e de ordinário encerra a descrição de um território, e nem por isso se confunde com a geografia, assim como se serve de fatos médicos e civis, sem que por isso com ela se confundam a Medicina e o conhecimento do governo civil. Esta confusão da Estatística é, pois como acabo de provar, inteiramente ilusória e aparente, que assinala os limites de cada uma, somente estabelece a seguinte verdade, e vem a ser, que as ciências mutuamente se auxiliam.

Assinados os pontos de demarcação a cada ciência pré-citada, destruídas todas as falsas considerações que o presente lhe as tinham confundido, e com identificado, a Estatística vem a ser uma ciência fundada em fatos, que tem por objeto apreciar a força, a riqueza e o poder de um Estado pela análise das fontes, e meios de conservação, de prosperidade e grandeza, que lhe oferecem seu território, sua população, suas produções, sua indústria, seu comércio externo, ou marítimo e interno, e seus exércitos. Em uma palavra, a Estatística é a ciência das forças reais e dos meios de poder de um Estado político.

A vista da rigorosa definição que acabo de expor, a estatística oferece oito partes gerais, que podem ainda subdividir-se segundo a exigência de diversas circunstâncias. $1^{\text {a }}$ extensão e divisões do território; $2^{\underline{a}}$ da população e suas relações diferentes com as outras partes da Estatística e da Economia Política; $3^{a}$ produções dos terrenos, das minas e pescas, e avaliação das riquezas que produzem; $4^{\mathrm{a}}$ indústria, sua importância, suas espécies, seus produtos e os salários que paga; $5^{\text {a }}$ comércio, seus meios, sua extensão e divisão, e suas relações com as outras fontes de riqueza; $6^{a}$ navegação mercante, seu estado, seu sistema e seus resultados na balança das forças nacionais; $7^{a}$ rendas do Estado, suas fontes, produto de cada uma, despesas da percepção, despesas do mesmo Estado, e uma exposição do sistema geral seguido na administração das nossas finanças; $8^{a}$ forças de terra e de mar, ou quadro dos diferentes corpos que os compõem, com a declaração circunstanciada de tudo, o que lhes pertence. Estas oito classes produziram as oito tabelas que aqui ajunto, e cuja exploração fora objeto do capítulo seguinte.

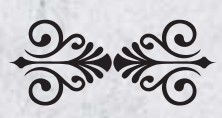

\section{Capítulo IV - Explicação das Tabelas e Algumas Reflexões}

1a A tabela do território compreende em primeiro lugar sua extensão, isto é, seu comprimento de Norte a Sul, sua largura de Leste a Oeste, e o número de suas léguas quadradas; em segundo lugar, suas divisões política, física e agrícola. A divisão política trata do número das comarcas, com que se divide a Província ou Capitania, e do número das vilas de cada uma, das administrações civil, militar, fiscal e eclesiástica, que regem e cooperam para o seu bom regime e do sistema da instituição pública. A divisão física dá a descrição das costas e portos, sé é marítima, das montanhas, sua direção, diferentes inclinações, dos rios, suas nascenças, seu curso, lugares por onde passam até o ponto em que deságuam, ou no oceano ou em outro rio; e a história sucinta de sua geologia, no que toca à mineralogia, e as qualidades internas do país. A divisão agrícola circuns- 
creve e classifica os diferentes terrenos da Província, segundo sua diferente natureza e fertilidade, e segundo a diversidade de suas produções.

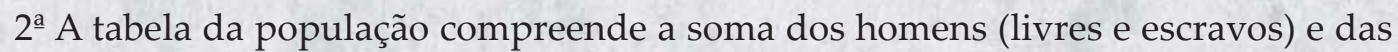
mulheres (livres e escravas), suas idades desde um até cem anos; a relação da população com os nascimentos (legítimos e naturais), com os casamentos, com os óbitos; e com os novos colonos que vieram para o país; as enfermidades que mais grassaram e suas causas. Trata, além disso, a referida tabela dos meios de animar e promover a povoação, como por exemplo, casas de expostos, casas de Misericórdia, hospitais, Casas de Caridade, Casas de Beneficência, para educação da pobreza, de alguns outros meios morais, ou de favor das rendas ou despesas feitas com iguais estabelecimentos, e da proporção entre os mortos e os enfermos, entrados por maior moral ou de favor, devem entender-se quaisquer concessão feitas a bem dos países de avultada família e do comércio, as sociedades particulares criadas com o fato de promover a colonização; as sociedades, para restituir os afogados à vida (human society dos Ingleses), as sociedades médicas, encarregadas de examinar as enfermidades endêmicas, as de mais curso e de descobrir seus antídotos para extirpá-las ou preveni-las, estabelecimentos estes que marcam a moralidade e beneficiam a nação, e para qual o governo deve com todo esmero dirigir o espírito público. Tratam por último dos obstáculos à povoação, quais: o clero secular e regular, ou frades, as freiras, das rendas dos conventos e da comparação com suas despesas. Esta última divisão deve merecer toda atenção da parte do governo, para um país novo, de progressão crescente, onde há abundância de empregos e lugar crescente e inteira falta de braços. Devia pelo contrário ser promovida em um país velho, estacionário, ou de progressão retrógrada, onde não há nem empregos, nem lugar; onde o termo da lei de reprodução da espécie é superior as correspondentes da lei de subsistência.

$3^{\text {a }}$ A tabela das produções compreende os produtos vegetais, animais e minerais e da pesca, cada um dos quais terá tantas subdivisões, quantas forem suas espécies; a quantidade anual de cada espécie de produto e por conseguinte seu valor; o produto líquido de toda renda territorial; o consumo destas produções no país; a população que vive ou de salário ou de parte do produto da renda; os salários e os lucros, ou parte do produto; a legislação administrativa das minas e dos bosques.

$4^{\mathrm{a}}$ A Tabela da indústria compreende na primeira divisão as artes e ofícios que se exercitam, por seus nomes e números, a classificação segundo estatutos particulares, o produto de direitos de patente, que consiste em uma contribuição anual, em virtude da qual todo vassalo adquire a faculdade de exercitar livremente sua profissão, o número de obreiros e dos homens, que vivem dos lucros da indústria, os salários e estes lucros. Na segunda divisão as manufaturas pela mesma forma, que as artes e ofícios, o número de artistas e dos homens que vivem de parte do produto da indústria, os salários e os lucros; a legislação seguida na administração das fábricas; por último, o consumo dos produtos da indústria, e o valor total do produto líquido dela.

$5^{\text {a }}$ A Tabela do Comércio compreende o comércio interno e externo, a quantidade de cada um dos gêneros ou produções exportados ou importados, que o comércio interno oferece, dos lugares de onde o exportam ou importam; do valor das exportações e importações internas. A segunda divisão trata do número e qualidade dos gêneros ou mercadorias exportadas e importadas, que este tráfico oferece ao consumo, dos portos 
onde se exportam ou importam, quer o comércio seja de cabotagem, quer estrangeiro; do valor das exportações e importações externas. A terceira divisão trata do número de homens que vivem ou de salários ou parte do lucro comercial; dos salários; e lucros do número de animais ocupados no comércio interno e por terra. A quarta divisão citada (fazendo a enumeração de mão), e do sistema administrativo para a sua conservação e reparo; da quantidade de numerário em circulação; dos barcos, se o houver, uma descrição de sua organização, época de sua criação, e o cálculo das utilidades que tem prestado já aos seus acionistas, comércio e indústria. Dos magistrados e tribunais encarregados do conhecimento de todas as questões mercantis e das leis administrativas do comércio. Notarei de passagem que o excesso das importações sobre as importações do comércio externo, assinala decisiva deterioração e decadência do Estado velho, é pelo contrário no Brasil país novo, e de progressão crescente, uma prova certa de sua prosperidade, porquanto à dívida contraída pelo acréscimo das importações, vem a ser um acréscimo de capitais, em vez de se consumirem sem produção, circulação e abram novos canais à acumulação; promovem todas as fontes de riqueza, dão vida a novos estabelecimentos rurais e industriais; melhoram as já existentes, oferecem anualmente um aumento proporcional das produções em todos os gêneros.

$6^{\text {a }}$ Trata da navegação; a navegação interna; a qual se subdivide em natural, ou pelos rios, e em artificial ou por canais, havendo cuidado de não esquecer o número de uns e de outros, e os pontos ou lugares onde vão ter os meios para esta navegação, como o número de barcos, e de homens que elas empregam, as frotas e os soldados; em segundo lugar compreende a navegação externa, ou seja, de cabotagem, ou para portos estranhos, o número de embarcações e de homens nela empregados; as frotas e os soldados. Trata por último esta tabela da polícia da navegação, das obrigações, a que pelas leis são sujeitos os navegantes e armadores no transporte das mercadorias entradas e saídas dos barcos, e formação das tripulações.

$7^{\text {a }}$ A tabela das rendas e despesas compreende em primeiro lugar o número das imposições diretas por classes [ilegível] Domínios e Bens Reais, os donativos voluntários dos vassalos nas urgências do Estado, correspondentes a cada uma das rendas mencionadas, debaixo da ordem mencionada; o modo ou sistema seguro na arrecadação ou percepção; o número de arrecadadores e administradores. Compreendem em segundo lugar, as despesas feitas com diversos funcionários que concorrem para o serviço em todos os ramos da administração, são divididas em civis, militares e eclesiásticas, e financeiras, e cada uma repartida ainda segundo suas diferentes classes deve entender-se como fazendo parte de alguma das quatro divisões referidas e, por conseguinte ser nela incluída toda e qualquer despesa, que lhe seja congênere, ou com elas tenha conexão; o número das despesas extraordinárias, como reparações de edifícios públicos, edificações de novas expedições temporárias, concessões ou gratificações para o fomento de diversas fontes de prosperidade pública. Trata por último essa tabela da legislação seguida na administração geral das finanças e valores correspondentes a cada uma das despesas aportadas, segundo se acha disposto na mesma tabela.

$8^{\mathrm{a}}$ A tabela das forças compreende na divisão das de terra, as tropas de primeira linha, classificadas segundo suas diferentes armas, e segundo o número de corpos, que contém cada arma; o número de praças de cada corpo; as tropas de segunda linha considerados 
debaixo das mesmas regras e ordem que as da primeira; os petrechos e provisões de guerra existentes, também por classes; os valores correspondentes a cada uma; compreende, na divisão das de mar, o Real Corpo da Marinha distribuída segundo a diferente graduação de suas patentes; a Artilharia do embarque; a tripulação ou equipagem dos rasos de guerra em atualidade de serviço; o número de praças de cada uma destas divisões; o número dos rasos de guerra e dos petrechos e provisões de guerra marítima, por suas classes; e finalmente os valores correspondentes de uns e de outros, o que dê o valor total de todos os meios existentes. Da reunião de todas as tabelas estatísticas, de todas as Províncias, ou Capitanias mandar-se extrair oito tabelas gerais, inalteravelmente fundadas nos princípios acima referidos, e com elas chegar-se-á ao conhecimento da totalidade das forças reais, e meios de poder deste vasto reino.

Quando o Ministério queira dar começo à indagação de todos os elementos, que entram na composição destas tabelas, indagação, que eu repito de subida, entidade para a boa direção de todas as suas medidas, podem elas servir de modelos para as que se houverem de mandar extrair nas diferentes capitanias, a seguir-se este método; ou ao menos podem encaminhar e dirigir os encarregados deste trabalho, quando, em vez do uso de Tabelas, escolham e prefiram antes o descrever por meio de Memórias a marcha e resultado dos seus exames, o que é melhor, porque então mencionando as bases, os princípios de que se serviram, podem ser retificados e coadjuvados pelo Ministério, se estes princípios fossem falsos ou pouco exatos; porque então reflexionando sobre alguns abusos, insinuados em qualquer das fontes da felicidade pública, pode o Ministério corrigi-los, ou extirpá-los. A multiplicidade e diferente natureza dos objetos compreendidos em iguais tabelas, pressupõe multiplicidade de homens, a quem deva ser confiada esta tarefa; e até insinua e inculca, quais destes devem com preferência ser escolhidos, por isso escuso de nomeá-los; a divisão neste caso, como em outros muitos, resume ou abrevia o tempo, facilita e promove o trabalho, e, por isso, deve ser um estímulo demais para que o Governo ouse tentá-lo; a síntese, porém, ou a coordenação e arranjo em um só todo sistemático, dos resultados espalhados de tantas e tão diversos elementos, deve ser partilha de um só homem, do lado das luzes e críticas precisas, de um só homem, como a unidade sintética por excelência. Não posso dissimular os obstáculos que há a vencer para levar ao cabo com igual projeto; estou mesmo convencido, que o resultado de alguns elementos será imperfeito nas primeiras tentativas, e não desconheço, que o resultado de outros para ser eliminado, esperará pelas luzes futuras de homens mais hábeis; mas apesar de tudo é melhor ter já alguma coisa, do que nada. Se todo projeto novo encontra dificuldades, as deste são sem dúvida veneíveis, e a glória de vencê-las reservada ao tempo, e a assiduidade dos sábios, deve animar-nos e não estremecer-nos. Por último, o amor do bem público, que ainda dura no coração dos bons portugueses, o desejo da estima e consideração que o Soberano e a Pátria tributam e consagra aos seus beneméritos, a sede das distorções, junta a constância do governo em prosseguir essa empresa, serão motivos muito poderosos, para que seus encarregados cuidem, a porfia, em aperfeiçoá-la e concluí-la; para que nos não defraudem de conhecimentos de tanta monta e de tanta utilidade.

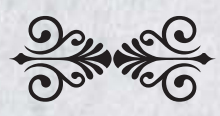




\section{Capítulo V - Resumo das Utilidades que o Estado Pode Colher de Iguais Conhecimentos Estatísticos}

Quando o Ministério, por meio de sua exata e rigorosa estatística do Brasil chegar ao conhecimento da extensão e riquezas naturais de seu território, sua população e das leis que esta segue em sua marcha e progresso dos produtos da agricultura, da indústria e do comércio; das rendas e das forças da terra, e mar que defendem a independência política deste Reino, e protegem o povo e seus trabalhos. Desde então o Ministério, não perdendo de vista a porção da riqueza empregada na produção da renda, vê-la-á subdividir-se por todas as fontes conhecidas de prosperidade pública; vê-la-á entreter em cada um destes empregos uma parte da população laboriosa e industriosa; vê-la-á preparar nestas grandes oficinas do trabalho geral todos os produtos, de que se compõem à renda particular e pública, todos os elementos da riqueza dos indivíduos, e do Estado. Desde então, ele poderá comparar as despesas com os produtos de cada emprego, determinar suas vantagens relativas, e absolutas, calcular aritmeticamente sua influência relativa sobre a riqueza, deduzir delas as regras que se devem religiosamente observar para sua formação, conservação, e progressivo aumento, e de todas as bases mencionadas inferir os princípios fundamentais de economia política, que devem encaminhá-lo no emprego mais vantajoso dos capitais e do trabalho. Desde então, seguindo emprego de cada um dos diversos produtos de trabalho, distinguindo cada emprego criado por cada supérfluo, demarcando suas respectivas utilidades, discernindo as causas naturais e artificiais, que acelerarão ou retardarão, que aumentarão ou minorarão a extensão de cada uma de suas beneficências, pondo um termo à existência de umas, dando mais vida e vigor à existência de outras, ele poderá extirpar abusos em sua nascença, ou inverterados, aperfeiçoar os métodos adotados e fazer novas combinações, ou para obter maiores produtos dos empregos antigos, ou para dar-lhes maior valor; e no estado atual da riqueza, nos processos usados, para conservá-la e promovê-la e, em seus resultados conhecidos, aventar os indícios de sua natureza, de suas causas, de seus princípios, de suas leis; desde então, em seus projetos de melhoramento, de ambição e de grandeza, ele poderá, contando com um sobrescrito mais ou menos certo de forças, junto do conhecimento da atualidade e progressos gradual de suas rendas, tentá-los e prossegui-los, assim como seguro da fraqueza e marcha retrógrada deles, abandoná-los, ou reservá-los para tempos mais prósperos e felizes, desde então, ele poderá finalmente, quando guerras calamitosas e inevitáveis, quando circunstâncias desastrosas e duráveis, agravarem sua renda habitual e secar uma fonte, benéfica de alguns dos ramos pelo impeço de alguns de seus trabalhos, poderá, digo contar com a outra parte da riqueza, não aplicada para produção de uma renda e só sim destinada a criar todos os objetos da comodidade, de gozos e de agrados, monumentos de luxo, da vaidade e da magnificência dos povos civilizados, e reguladores dos diferentes graus de sua civilização, riqueza esta, que, por dever conservar-se intata e sagrada em todas as circunstâncias ordinárias do Estado, deixou de representar seu papel na Memória, que ofereço, e de ter um lugar nas tabelas que ajunto.

Do resumo de todas as utilidades expendidas pode concluir-se que o Ministério, pelo quadro de riqueza do seu emprego, e de seus produtos, chegará, não só ao conhecimento das causas da riqueza de sua nação, mas também ao estabelecimento dos princípios criados da riqueza moderna, e dos verdadeiros meios de poder, e de força. 
Conheço a importância e dificuldades da matéria que acabo de discutir, e por isso é natural, que caísse em mil defeitos; conheço que a tarefa, de que me encarreguei, é superior à debilidade de minhas forças. Mas se nas belas-artes a mediocridade deve condenarse ao silêncio, porque deprava o gosto; nas ciências ela é útil porque ajuntando os materiais e dispondo-os, chama em seu socorro a mão de poder; da sabedoria e do gênio, para que melhor coordene e ponha em obra, eis o que me animou nesse trabalho. Se o minguado e fraco serviço que ofereço puderem ser úteis ao meu Soberano e a minha Pátria, está satisfeita minha ambição, estão pagas minhas fadigas.

\section{Tabelas}

Tabela 1

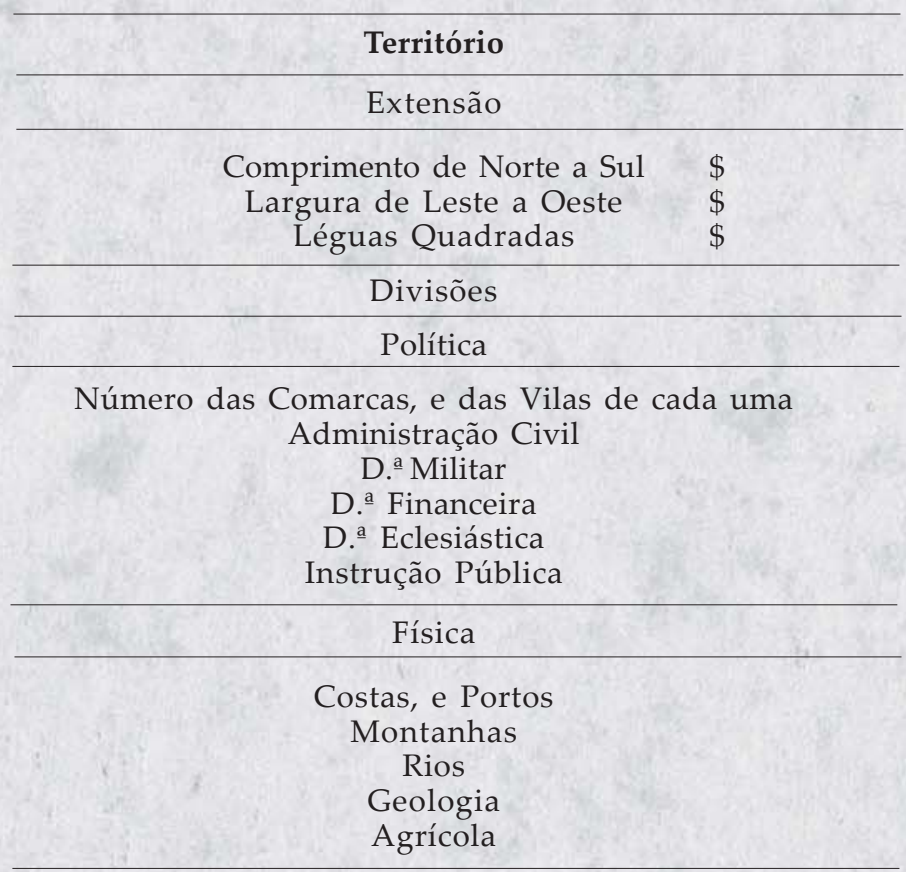

Circunscrição do território segundo sua diversa natureza; e fertilidade; segundo a diversidade de suas produções 
Tabela 2

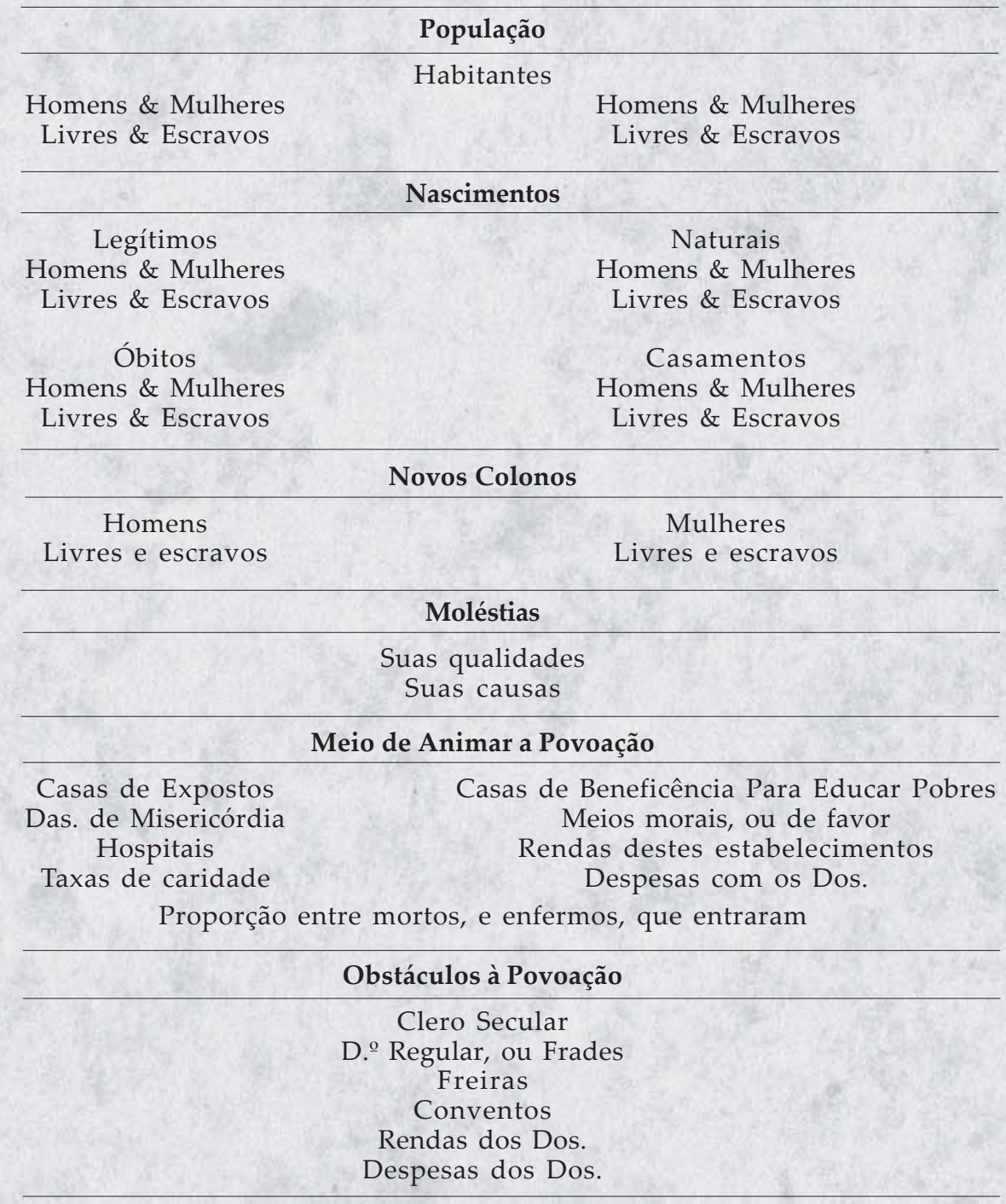


Tabela 3

\begin{tabular}{c}
\hline Produções \\
\hline Primeira Divisão \\
Vegetais \\
Animais \\
Das Minas \\
\hline Segunda Divisão \\
\hline Quantidades de Cada Uma \\
Valores de Cada Uma \\
População que viva: ou de salários, ou de parte do produto \\
Salários, ou Lucros \\
Troduto Líquido de Toda a Renda Territorial \\
Terceira Divisão \\
\hline Legislação Administrativa das Minas \\
D. dos bosques
\end{tabular}

Tabela 4

Indústria

Primeira Divisão

Artes e Ofícios

Polícias das Mesmas

Produto dos Direitos de Patente

Obreiros, e homens que vivem de parte dos lucros da indústria Salários e Lucros

\begin{tabular}{c} 
Segunda Divisão \\
Manufaturas \\
Artistas, e homens que vivem de parte do produto delas \\
Salários e Lucros \\
Administração das Fábricas \\
Terceira Divisão \\
\hline Consumo dos Produtos da Indústria \\
Valor Total do Produto Líquido Dela
\end{tabular}


Tabela 5

\begin{tabular}{c} 
Comércio \\
Interno \\
\hline $\begin{array}{c}\text { Gêneros, ou produções, que ele oferece ao consumo } \\
\text { Lugares onde se exportam, ou importam. } \\
\text { Valor das Exportações } \\
\text { Dos Produtos Territoriais / } \\
\text { Dos Lucros da Indústria } \\
\text { Dos Produtos Territoriais / } \\
\text { Dos Lucros da Indústria }\end{array}$ \\
\hline Externo \\
\hline Gêneros, ou produções, que ele oferece ao consumo \\
Lugares onde se exportam, ou importam.
\end{tabular}

Tabela 6

\begin{tabular}{c}
\hline Navegação \\
\hline Interna \\
\hline Natural \\
Artificial \\
Barcos \\
Tripulação \\
Frotas \\
Soldadas \\
Externa \\
\hline
\end{tabular}

Costeira, ou de cabotagem

Colonial

Estrangeira

Embarcações

Tripulação, ou Equipagem

Frotas

Soldadas

Polícia da Navegação Externa e Interna 
Tabela 7

\begin{tabular}{cc}
\hline \multicolumn{2}{c}{ Rendas } \\
\hline Diretas \$ & Valores Correspondentes \$ \\
Indiretas \$ & D. $\$$ \\
Extraordinárias \$ & D. $\$$ \\
Modo de arrecadação, ou percepção \\
Administradores, ou arrecadadores \\
\hline \multicolumn{2}{c}{ Despesas } \\
\hline Civis \$ & Valores Correspondentes \\
Militares \$ & Dos. \\
Eclesiásticas \$ & Dos. \\
Do fisco \$ & Dos. \\
Extraordinários \$ & Dos. \\
\hline
\end{tabular}

Sistema Financeiro

Legislação da Administração Geral de Finanças

Tabela 8

\begin{tabular}{cl}
\hline \multicolumn{2}{c}{ Forças da Terra } \\
\hline $1^{a}$ Linha & $2^{a}$ linha \\
\hline Engenharia $\$$ & Zero \\
Artilharia $\$$ & $\$$ \\
Infantaria $\$$ & $\$$ \\
Cavalaria $\$$ & $\$$ \\
\hline Petrechos, e Valores \\
Provisões de guerra \\
\hline \multicolumn{2}{c}{ Forças de Mar } \\
\hline Real Corpo de Marinha $\$$ \\
Artilharia de Embarque $\$$ \\
\multicolumn{2}{c}{ Tripulação $\$$} \\
\hline Vasos de Guerra & Valores \\
Petrechos e Provisões \\
\hline \multicolumn{2}{c}{} \\
\hline
\end{tabular}

